\title{
ANTIMICROBIAL ACTIVITY OF SOME POTENTIAL GREEN ALGAL STRAINS ISOLATED FROM BUNDELKHAND REGION UTTAR PRADESH
}

\author{
NEHA SRIVASTAVA ${ }^{\mathbf{1}}$, M. R. SUSEELA ${ }^{2}$, KIRAN TOPPO $^{\mathbf{3}}$ \& RUBINA LAWRENCE ${ }^{\mathbf{4}}$ \\ ${ }^{1,2,3}$ Algology Laboratory, CSIR-National Botanical Research Institute, Luck now, Uttar Pradesh, India \\ ${ }^{4}$ Departments of Microbiology \& Fermentation Technology SHIATS Allahabad, Uttar Pradesh, India
}

\begin{abstract}
Objective

To study antimicrobial activity of some potential green algal strains viz., Scenedesmus abundans, Nannochloropsis oculata and Spirogyra condensata, against four human bacterial pethogens.

Methods
\end{abstract}

The characterization of the antimicrobial activity was used disc diffusion method against four human pathogenic bacteria viz., Escherichia coli, Staphylococcus aereus, Bacillus cereus and Pseudomonas aerugenosa. Streptomycin disc were used as a positive control and only solvent were used as a negative control.

Results

The methanolic extract of Scenedesmus abundans, Nannochloropsis oculata, and Spirogyra condensata showed the antibacterial activity against four pathogenic bacteria viz., Escherichia coli, Staphylococcus aereus, Bacillus cereus and Pseudomonas aerugenosa with the inhibition zone $(15,16,22,17 \mathrm{~mm})(15,15,26,17 \mathrm{~mm})$ and $(25,16,26,20 \mathrm{~mm})$ respectively. The ethanolic extract of Scenedesmus abundans, Nannochloropsis oculata, and Spirogyra condensata showed the antibacterial activity against four pathogens viz, Escherichia coli, Staphylococcus aereus, Bacillus cereus and Pseudomonas aerugenosa with the inhibition zone $(20,23,23,21 \mathrm{~mm})(19,25,33,24 \mathrm{~mm})$ and $(24,23,32,22 \mathrm{~mm})$ respectively. The acetone extract of Scenedesmus abundans, Nannochloropsis oculata, and Spirogyra condensata showed the antibacterial activity against four pathogens viz., Escherichia coli, Staphylococcus aereus, Bacillus cereus and Pseudomonas aerugenosa, with the inhibition zone $(18,34,23,20 \mathrm{~mm})(00,17,28,12 \mathrm{~mm})$ and $(17,13,15,15)$ respectively. The di ethyl ether extract of Scenedesmus abundans, Nannochloropsis oculata, and Spirogyra condensata showed the antibacterial activity against four pathogens viz., Escherichia coli, Staphylococcus aereus, Bacillus cereus and Pseudomonas aerugenosa with the inhibition zone $(18,29,17,15 \mathrm{~mm})(00,10,12,15 \mathrm{~mm})$ and $(00,15,8,9 \mathrm{~mm})$ respectively. Streptomycin disc showed the antibacterial activity againt four pathogens viz., Escherichia coli, Staphylococcus aereus, Bacillus cereus and Pseudomonas aerugenosa with the inhibition zones of 28, 15, and $22 \mathrm{~mm}$ respectively.

Conclusions

The present studies conclude that acetone extract of Scenedesmus abundans showed the maximum antibacterial activity against Staphylococcus aereus with the inhibition zone $34 \mathrm{~mm}$. The ethanolic extract of Nannochloropsis oculata showed the maximum antibacterial activity against Bacillus cereus with the inhibition zone $33 \mathrm{~mm}$. The ethanolic extract of Spirogyra condensata showed the maximum antibacterial activity against Bacillus cereus with the inhibition zone 32 mm with reference to antibiotic disc Streptomycin showed antibacterial activity against Staphylococcus aereus with the inhibition zone $15 \mathrm{~mm}$ where as antibacterial activity against Bacillus cereus with the inhibition zone $28 \mathrm{~mm}$. Further phytochemical studies are needed to elucidate the components responsible for antibacterial activity of these extract against bacteria. 
KEYWORDS: Green Algae Scenedesmus Abundans, Nannochloropsis Oculata, Spirogyra Condensata Antimicrobial Activity, Bundelkhand \& Region

Received: Jul 08, 2017; Accepted: Jul 31, 2017; Published: Aug 11, 2017; Paper Id.: IJMPSAUG20173

\section{INTRODUCTION}

Since ancient times the emergence of modern approaches, the drug discovery and the pace of drug development has slowed down, because of lack of proper lead in biomolecules, which is crucial to designing newer drug [6]. Pharmaceutical market is growing rapidly and continuously. But, still the demand for new drug discovery is encouraged. The reason behind this motivation can be the growing numbers of drug- resistant infectious disease and more and more upcoming disorder causing by bacteria. The terrestrial resources have been greatly explored and the academic and industry researchers are striving to get lead molecules from the inner space of oceans [8]. Microalgae are a diverse group of photosynthetic microorganisms found in everywhere like ocean, lakes, rivers, ponds, puddles, moist surfaces and fresh water etc [11]. Microalgae represent a unique opportunity to discover novel metabolites at lower costs. However microbial metabolites produced by microalgae. Microalgae are highly potential source of bioactive molecules which are able to produce some biological activities such as antibacterial, antiviral, antifungal and anticancer [1]. These organisms are rich source of amino acids, terpenoids, phlorotannins, steroids, phenolic compounds, halogenated ketones, alkenes and cyclic polysulphides [9, 10]. Secondary or primary metabolites produced by these organisms may be potential bioactive compounds of interests in the pharmaceutical industry [2, 3, and 4]. The bioactive compound from the algae is investigated for their antimicrobial activities as the pathogenic microbes are becoming resistant to the synthetic drug. According to the world Health Organisation (WHO), approximately $80 \%$ of the world population depends on traditional remedies for their primary health care needs [16]. Microalgae have for long time been used with therapeutic purposes and their systematic screening for biologically active compounds began in 1950s. The different solvent extracts from microalgae were tested against gram positive and gram negative bacteria. The antimicrobial compounds are fatty acids, acrylic acids, halogenated aliphatic compounds, terpenes, sulphur containing hetero cyclic compounds, carbohydrates and phenols [20]. Temperature of incubation, $\mathrm{pH}$ of the culture medium, incubation period, medium constituents and light intensity are the important factors influencing the production of antimicrobial agents [5]. The antibacterial properties of a Chlorophycean green alga, Scenedesmus sp. isolated from a natural pond were tested against three different pathogenic bacterial strains [27]. With this knowledge the present study was aimed to screen the antimicrobial potential of Scenedesmus abundans, Nannochloropsis oculata and Spirogyra condensata against human bacterial pathogens. The first antibacterial compound isolated from a microalgae and chlorella; a mixture of fatty acids, viz., chlorellin which was found to be responsible for the inhibitory activity against Gram +ve and Gram -ve bacteria [21, 7].

\section{MATERIALS AND METHODS}

\section{Collection of the Microalgal Strains and Bacterial Strains}

Fresh water algal samples were collected with $100 \mathrm{ml}$ capacity plastic bottles during winter session from Bundelkhand region Uttar Pradesh (U.P.) in Central India. It is located between $23^{\circ} 20^{\prime}$ and $26^{\circ} 20^{\prime}$ N latitude and $78^{\circ} 20^{\prime}$ and $81^{\circ} 40^{\prime}$ E longitude. Where Nannochloropsis oculata were collected from Chhabi pond of Banda, Scenedesmus abundans were collected from Mandakani river of Chitrakoot and Spirogyra condensata were collected from atiya tal of 
Jhansi. Human bacterial pathogens like Bacillus cereus-MCCB0061, Staphylococcus aereous-MCCB0045, Escherichia coli-MCCB0016 and Pseudomonas aerugenosa-MCCB0035 were obtained from department of microbiology \& Fermentation Technology SHIATS Allahabad (U.P.), India. Bacterial strains were inoculating on to in nutrient broth and incubated at $37^{\circ} \mathrm{C}$ for $24 \mathrm{hrs}$.

\section{Isolation and Growth Condition of Microalgal Strains}

Microalgae were isolated from fresh water algal samples. After purification, the culture was grown in BG-11 medium. The cultures were grown autotrophically in the batch culture, in haffkins flasks and were kept in the culture room. Culture condition was maintained such as temperature $27^{\circ} \mathrm{c}+0.5^{\circ} \mathrm{c}$; $\mathrm{pH}$ rang 7 to 7.5 of culture medium, incubation period 2 months and 3000 lux light intensity.

\section{Identification of Microalgal Strain}

Microscopic observation of algal samples was done by Lieca DM. 500 research microscope and microphotography was done with attached camera Ec-3 [17]. Morphological observation presence of chloroplast shape and size of cells were taken into consideration. The identification of taxa was done by referring standard taxonomic manuals of Philipose [18] and Prescott [19].

\section{Growth Analysis and Biomass Productivity}

Growth rate of cultures was determined by measuring the optical density (O.D.) at $680 \mathrm{~nm}$ using UV-VIS Spectrophotometer (Spectrascan UV 2700, Thermo Scientific). For the measurement of optical density, $2 \mathrm{ml}$ culture was drawn from the culture flask at the regular measure of alternate days. The samples were diluted so that the value of $\mathrm{OD}_{680}$ falls between the ranges of 0.2-0.8, actual OD was determined by multiplying the dilution factor with value of OD.

\section{Extraction of Microalgal Biomass}

Biomass of microalgae was harvested after 40 and 60 days respectively. The harvested biomass was centrifuged at $10000 \mathrm{rpm}$ for $7 \mathrm{~min}$ and pellet was lyophilized. $250 \mathrm{mg}$ of lyophilized algal powder was taken in four different $50 \mathrm{ml}$ capacity conical flask and mix with $15 \mathrm{ml}$ four different solvents such as methanol, ethanol, acetone and diethyl ether. The mixture was shaken overnight in orbital shaker, centrifuged at $10000 \mathrm{rpm}$ for 10min in twice and supernatant was taken. Supernatant was dried in a rotary evaporator at $40^{\circ} \mathrm{C}$. The algal extract dissolved in $1 \mathrm{ml}$ four different solvents used for antimicrobial activity and preserved in $4^{\circ} \mathrm{c}$ for further use [12].

\section{Disc Diffusion Method}

Antibacterial activity of microalgae was used by disc diffusion method [13, 14]. For the disc diffusion assay 400 $\mu \mathrm{L}$ of each bacterial suspension was uniformly spread on a solid nutrient agar medium in a petri dish. Two sterile paper disks (6 $\mathrm{mm}$ in diameter whatman filter paper) and one streptomycin disc were placed on the surface of each nutrient agar plate and were impregnated with $20 \mu \mathrm{L}$ of the diluted algal extract. Plates were incubated for $24 \mathrm{~h}$ under appropriate culture conditions [15]. Disc impregnated with algal extract and methanol, ethanol, acetone and diethyl ether served as negative controls and a disk with an antibiotic (Streptomycin) served as a positive control. The antibacterial activity was using (ethanol, methanol, acetone and diethyl ether) algal extract. 


\section{RESULTS}

\section{Growth Analysis and Biomass Productivity}

The biomass contained found in Scenedesmus abundans $0.48943 \mathrm{~g} / \mathrm{L}$, Nannochloropsis oculata $0.53316 \mathrm{~g} / \mathrm{L}$ and Spirogyra condensata $0.37916 \mathrm{~g} / \mathrm{L}$.

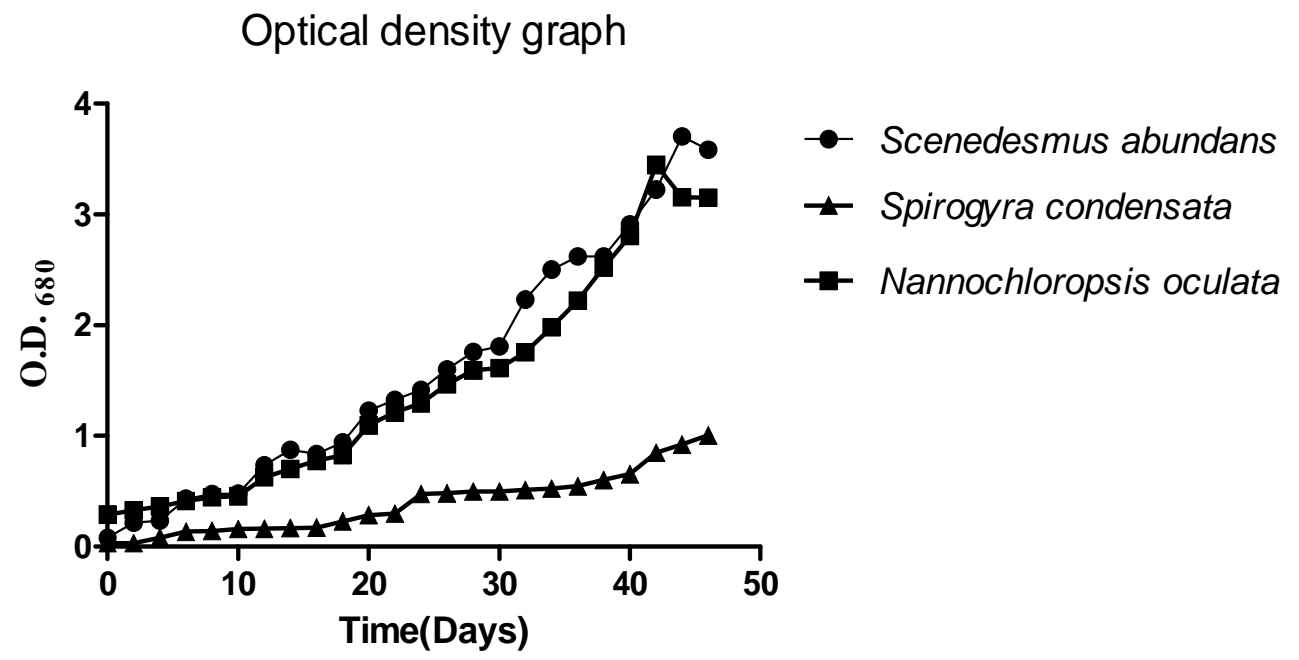

Figure 1

\section{Antibacterial Activity of Different Algal Strain in Different Solvants}

In the present study the methanolic, ethanolic, acetone and diethyl ether were tested for antibacterial activity against four human bacterial pathogens. The methanolic extract of Scenedesmus sp. showed the antibacterial activity against four bacterial pathogens viz., B. Cereus, P. aerugenosa, S. aereus and E. Coli, with the inhibition zone of 22,17 , 16 and $15 \mathrm{~mm}$, respectively. The ethanolic extract of Scenedesmus abundans showed the antibacterial activity against four bacterial pathogens viz., B. cereus, P. aerugenosa, S. aereus and E. Coli with the inhibition zone of 23, 21, 23 and $20 \mathrm{~mm}$, respectively. The acetone extract of Scenedesmus abundans showed the antibacterial pathogens viz., B. cereus, $P$. aerugenosa, S. aereus and E. Coli with the zone of inhibition zone of 23, 20, 34 and $18 \mathrm{~mm}$, respectively. The diethyl ether extract of Scenedesmus abundans showed the antibacterial activity against four bacterial pathogens viz., B. cereus, $P$. aerugenosa, S. aereus and E. Coli 17, 15, 29 and $18 \mathrm{~mm}$, respectively. The methanolic extract of Nannochloropsis oculata showed the antibacterial activity against four bacterial pathogens viz., B. Cereus, P. aerugenosa, S. aereus and E. coli with the inhibition zone of 26,17, 15 and $15 \mathrm{~mm}$, respectively. The ethanolic extract of Nannochloropsis oculata showed the antibacterial activity against four bacterial pathogens viz., B. cereus, P. aerugenosa, S. aereus and E. coli with the inhibition zone of 33, 24, 25 and $19 \mathrm{~mm}$, respectively. The acetone extract of Nannochloropsis oculata showed the antibacterial pathogens viz., B. cereus, P. aerugenosa, S. aereus and E. coli with the zone of inhibition zone of $28,12,17$ and $00 \mathrm{~mm}$, respectively. The diethyl ether extract of Nannochloropsis oculata showed the antibacterial activity against four bacterial pathogens viz., B. cereus, P. aerugenosa, S. aereus and E. coli 12, 15, 10 and 00 mm, respectively. The methanolic extract of Spirogyra condensata, showed the antibacterial activity against four bacterial pathogens viz., $B$. Cereus, P. aerugenosa, S. aereus and E. coli with inhibition zone of 26, 20, 16, and $25 \mathrm{~mm}$, respectively. The ethanolic extract of Spirogyra condensata showed the antibacterial activity against four bacterial pathogens viz., B. cereus, $P$. aerugenosa, S. aereus and E. Coli with the inhibition zone of 32, 22, 23 and $24 \mathrm{~mm}$, respectively. The acetone extract of 
Spirogyra condensata, showed the antibacterial pathogens viz., B. cereus, P. aerugenosa, S. aereus and E. coli with the zone of inhibition zone of 15, 15, 13, $17 \mathrm{~mm}$, respectively. The diethyl ether extract of Spirogyra condensate showed the antibacterial activity against four bacterial pathogens viz., B. cereus, P. aerugenosa, S. aereus and E. coli with the inhibition zone of 8, 9, 15, $00 \mathrm{~mm}$, respectively. The negative control only for solvents In methanol solvent showed antibacterial activity against four bacterial pathogens viz., B. cereus, P. aerugenosa, S. aereus and E. coli 00, 09, 00 and 07 mm., respectively. In ethanol solvent showed antibacterial activity against four bacterial pathogens viz., B. cereus, $P$. aerugenosa, S. aereus and E.coli 12, 11, 00 and $07 \mathrm{~mm}$. respectively. In acetone solvent showed antibacterial activity against four bacterial pathogens viz., B. cereus, P. aerugenosa, S. aereus and E.coli 13, 15, 00 and $10 \mathrm{~mm}$. respectively. In diethyl ether solvent showed antibacterial activity against four bacterial pathogens viz., B. cereus, P. aerugenosa, S. aereus and E.coli 00, 11, 00 and $00 \mathrm{~mm}$. respectively. Source of antibacterial activity keeping Streptomycin disc were used as a positive control against four bacterial pathogens viz., B. cereus, P. aerugenosa, S. aereus and E.coli zone of inhibition 17, 22,15 and $28 \mathrm{~mm}$. respectively.

\section{Antibacterial Activity of Various Algal Extract in Different Solvents}

Table 1

\begin{tabular}{|c|c|c|c|c|c|c|c|c|c|c|c|c|c|c|}
\hline \multirow{3}{*}{ Algal Species } & \multirow{3}{*}{ Extracts } & \multirow{3}{*}{$\begin{array}{l}\text { Concentration } \\
(\mathrm{mg} / \mathrm{mL})\end{array}$} & \multicolumn{12}{|c|}{ Inhibition Zone Diameter (mm) } \\
\hline & & & \multicolumn{3}{|c|}{ E. Coli } & \multicolumn{3}{|c|}{ S. Aureus } & \multicolumn{3}{|c|}{ P. Aerugenosa } & \multicolumn{3}{|c|}{ B. Cereus } \\
\hline & & & $\mathbf{A E}$ & $\mathrm{NC}$ & PC & $\mathbf{A E}$ & $\mathrm{NC}$ & PC & $\mathbf{A E}$ & $\mathrm{NC}$ & $\mathrm{PC}$ & $\mathbf{A E}$ & $\mathrm{NC}$ & $\mathrm{PC}$ \\
\hline \multirow[t]{4}{*}{ Scenedesmus abundans } & Methanol & 0.0039 & 15 & 7 & \multirow{4}{*}{28} & 16 & - & \multirow{4}{*}{15} & 17 & 9 & \multirow{4}{*}{22} & 22 & - & \multirow{4}{*}{17} \\
\hline & Ethanol & 0.0010 & 20 & 7 & & 23 & - & & 21 & 11 & & 23 & 12 & \\
\hline & Acetone & 0.0010 & 18 & 10 & & 34 & - & & 20 & 15 & & 23 & 13 & \\
\hline & Diethyl ether & 0.0017 & 18 & - & & 29 & - & & 15 & 11 & & 17 & - & \\
\hline \multirow{4}{*}{ Nannochloropsis oculata } & Methanol & 0.0050 & 15 & 7 & \multirow{4}{*}{28} & 15 & - & \multirow{4}{*}{15} & 17 & 9 & \multirow{4}{*}{22} & 26 & - & \multirow{4}{*}{17} \\
\hline & Ethanol & 0.0014 & 19 & 7 & & 25 & - & & 24 & 11 & & 33 & 12 & \\
\hline & Acetone & 0.0011 & - & 10 & & 17 & - & & 12 & 15 & & 28 & 13 & \\
\hline & Diethyl ether & 0.0003 & - & - & & 10 & - & & 15 & 11 & & 12 & - & \\
\hline \multirow{4}{*}{ Spirogyra codensata } & Methanol & 0.0026 & 25 & 7 & \multirow{4}{*}{28} & 16 & - & \multirow{4}{*}{15} & 20 & 9 & \multirow{4}{*}{22} & 26 & - & \multirow{4}{*}{17} \\
\hline & Ethanol & 0.0015 & 24 & 7 & & 23 & - & & 22 & 11 & & 32 & 12 & \\
\hline & Acetone & 0.0006 & 17 & 10 & & 13 & - & & 15 & 15 & & 15 & 13 & \\
\hline & Diethyl ether & 0.0014 & - & - & & 15 & - & & 9 & 11 & & 8 & - & \\
\hline
\end{tabular}

AE: algal extract; NC: Negative control; PC: Positive control

Nannochloropsis Oculata Shows Antibacterial Activity against Four Pathogenic Bacteria in Four Different Solvent
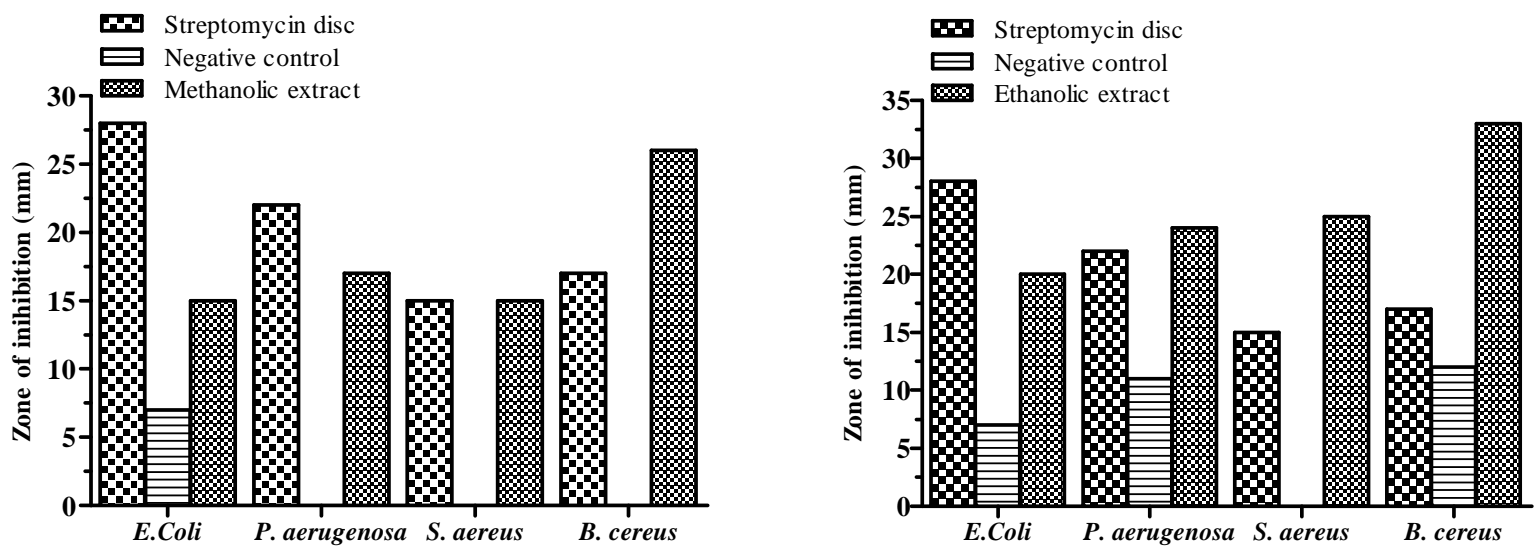

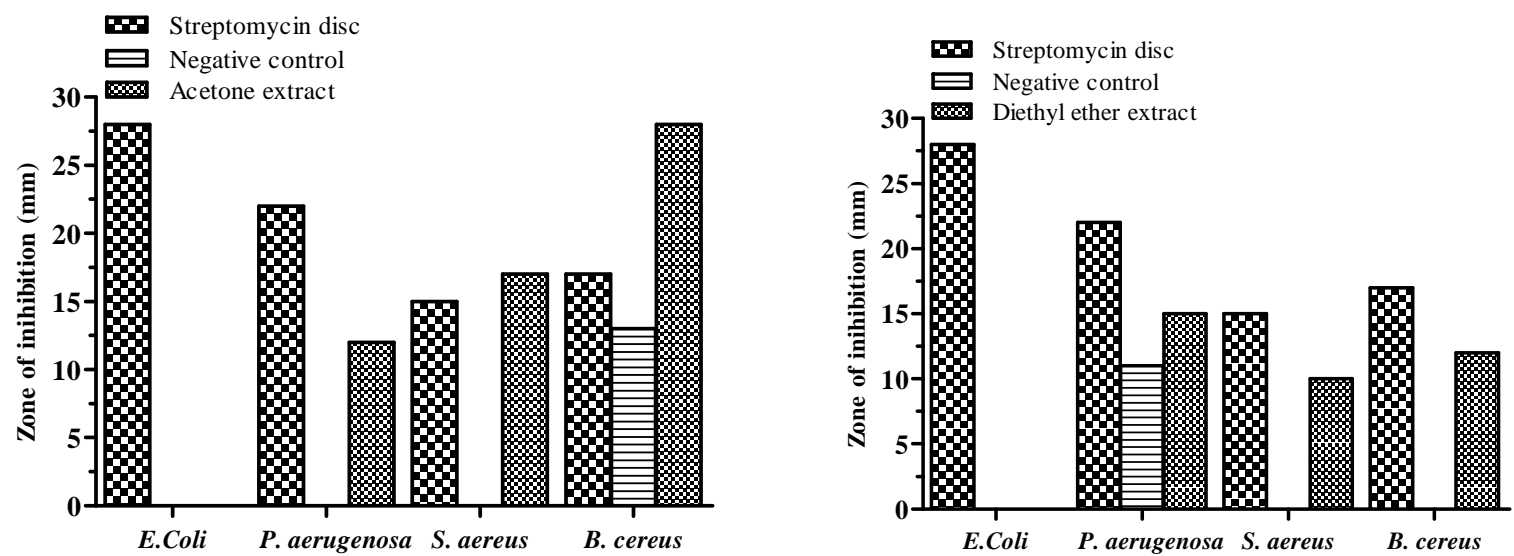

Figure 2

The Plates Showed Antimicrobial Activity of Nannochloropsis Oculata against Four Pathogenic Bacteria in Four Different Solvents

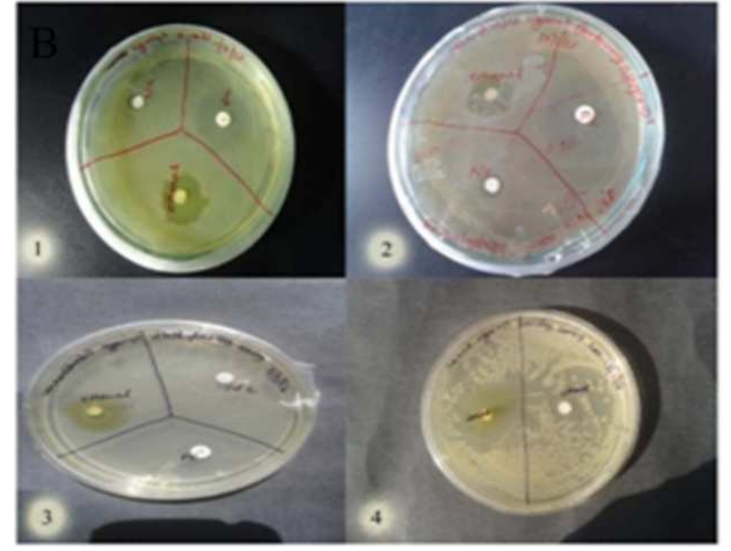

4. Nannochloropsis Oculata Shows the Maximum Antibacterial Activity in Ethanolic Extract against B. Cereus

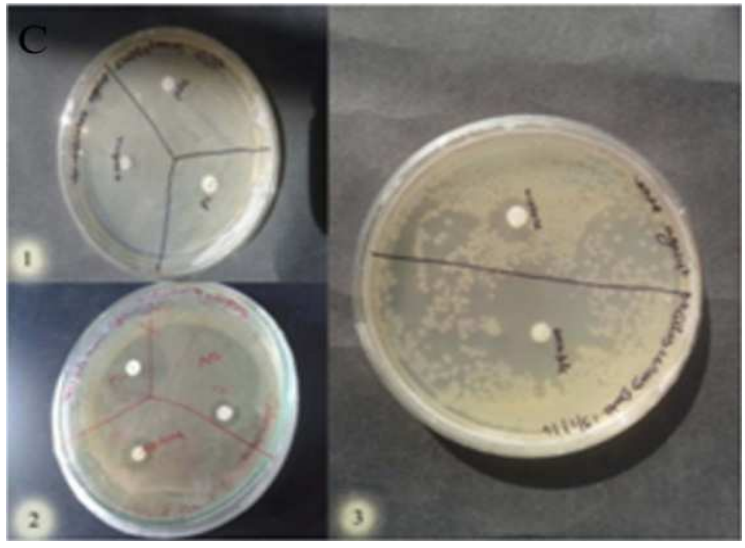

4. Nannochloropsis Oculata Shows the Maximum Antibacterial Activity in Acetone Extract against B. Cereus

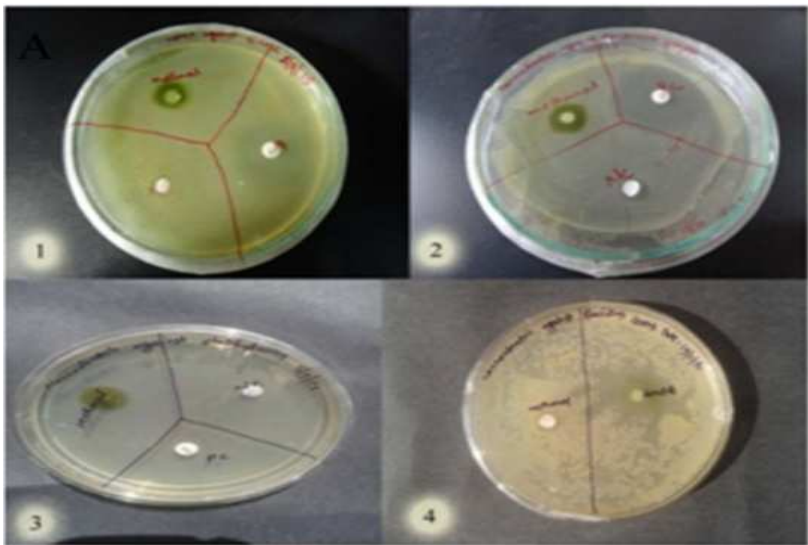

4. Nannochloropsis Oculata Shows the Maximum Antibacterial Activity in Methanolic Extract against $B$. Cereus

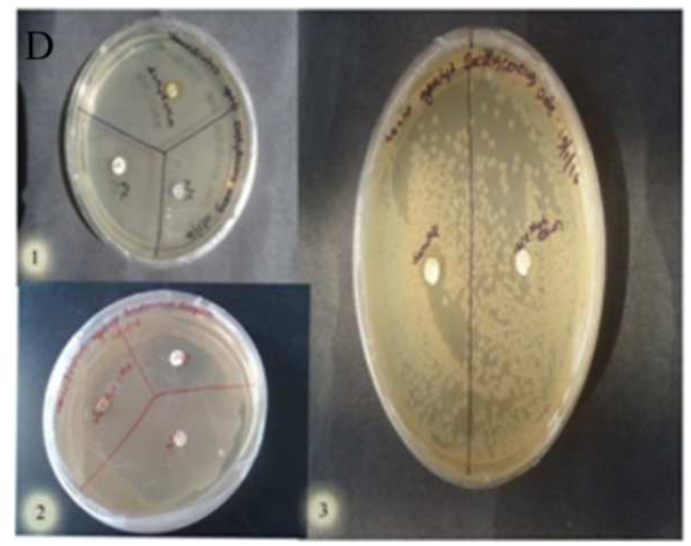

2. Nannochloropsis Oculata Shows the Maximum Antibacterial Activity in Di Etylether Extract against $P$. Aerugenosa

Figure 3 
A.Methanolic extract of Nannochloropsis shows antibacterial against four different bacteria (1) E. coli (2) P.aerugenosa (3) S.aereus (4) B. cereus

B. Ethanolic extract of Nannochloropsis shows antibacterial against four different bacteria (1) E. coli (2) P.aerugenosa (3) S. aereus (4) B.cereus

C.Acetone extract of Nannochloropsis shows antibacterial against four different bacteria (1) E. coli (2) P.aerugenosa (3) S.aereus (4) B. cereus

D.Diethyl ether extract of Nannochloropsis shows antibacterial against four different bacteria (1) E.coli (2) P. aerugenosa (3) S.aereus (4) B. cereus

\section{Scenedesmus Abundans Shows Antibacterial Activity against Four Pathogenic Bacteria in Four Different Solvent}
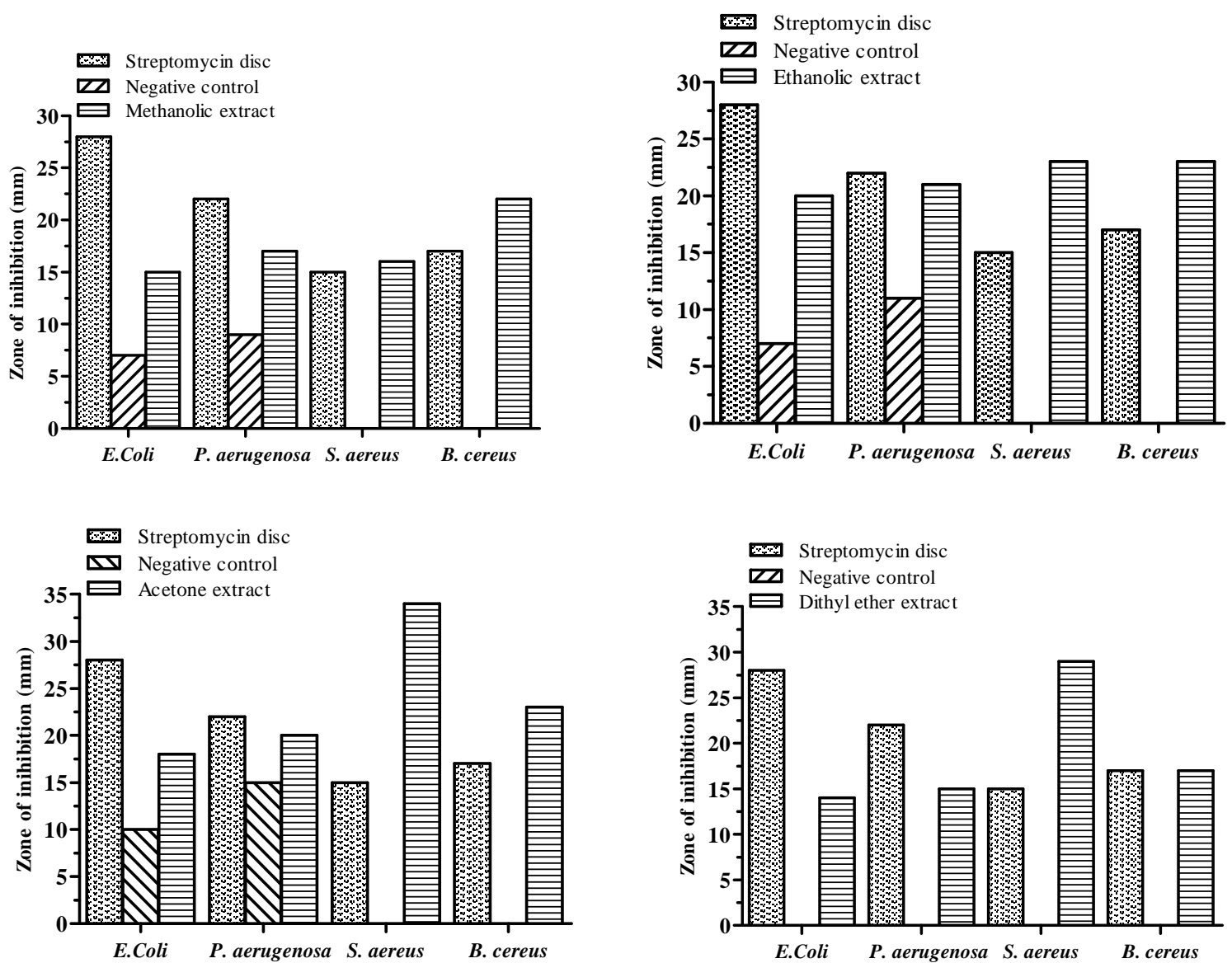

Figure 4 
The Plates Showed Antimicrobial Activity of Scenedesmus Abundans against Four Pathogenic Bacteria in Four

\section{Different Solvents}

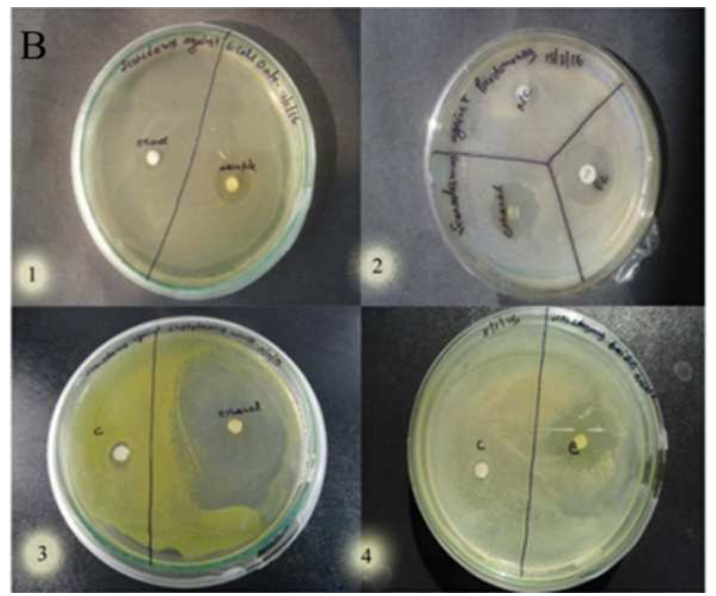

4. Scenedesmus Abundans Shows the Maximum Antibacterial Activity in Methanolic Extract against $B$. Cereus

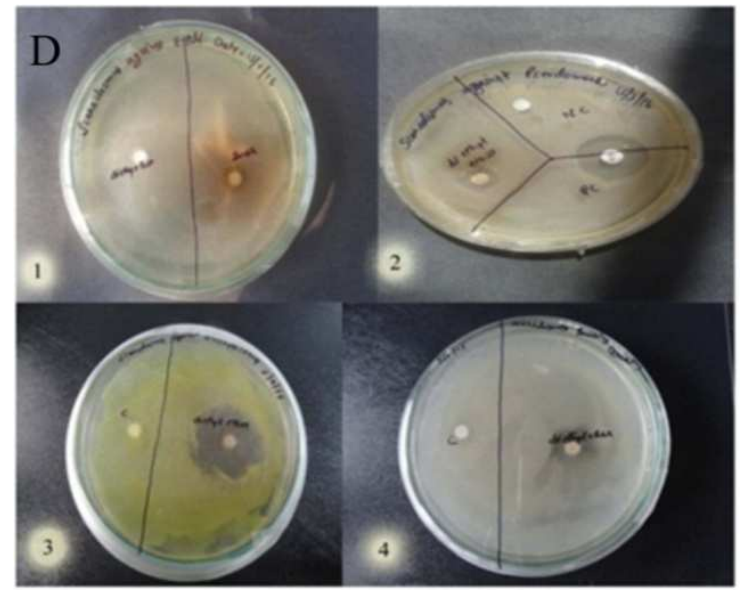

4. Scenedesmus Abundans Shows the Maximum Antibacterial Activity in Acetone Extract against $S$. aereus

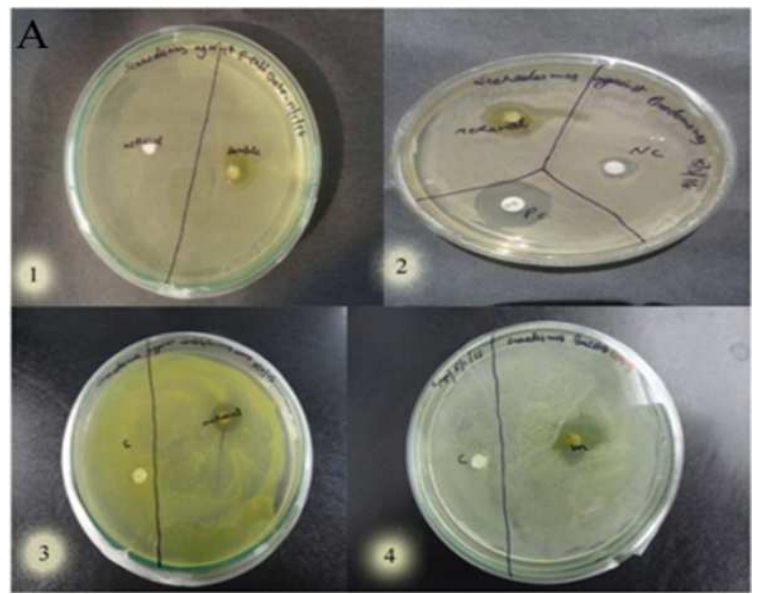

3\&4.Scenedesmus Abundans Shows the Maximum Antibacterial Activity in Ethanolic Extract against $S$. Aereus \& B. Cereus Bacillucereus

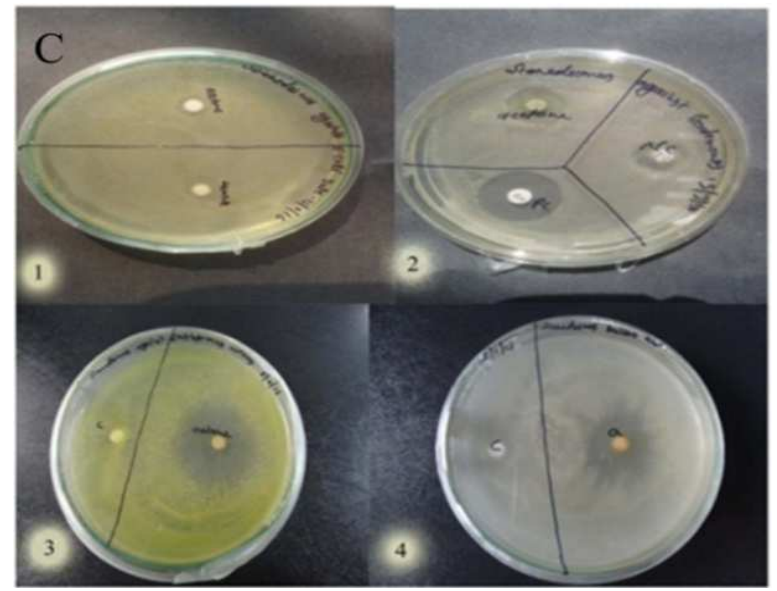

4. Scenedesmus Abundans Shows the Maximum Antibacterial Activity in Diethyl Ether Extract against $S$. aereus

Figure 5

A. Methanolic extract of Scenedesmus shows antibacterial against four different bacteria (1) E. coli (2) P.aerugenosa (3) S.aereus (4) B. cereus

B. Ethanolic extract of Scenedesmus shows antibacterial against four different bacteria (1) E. coli (2) P.aerugenosa (3) S. aereus (4) B.cereus

C. Acetone extract of Scenedesmus shows antibacterial against four different bacteria (1) E. coli (2) P.aerugenosa

(3) S.aereus (4) B. cereus

D. Diethyl ether extract of Scenedesmus shows antibacterial against four different bacteria (1) E.coli (2) P. aerugenosa (3) S.aereus (4) B. cereus 
Spirogyra Condensata Shows Antibacterial Activity against Four Pathogenic Bacteria in Four Different Solvent
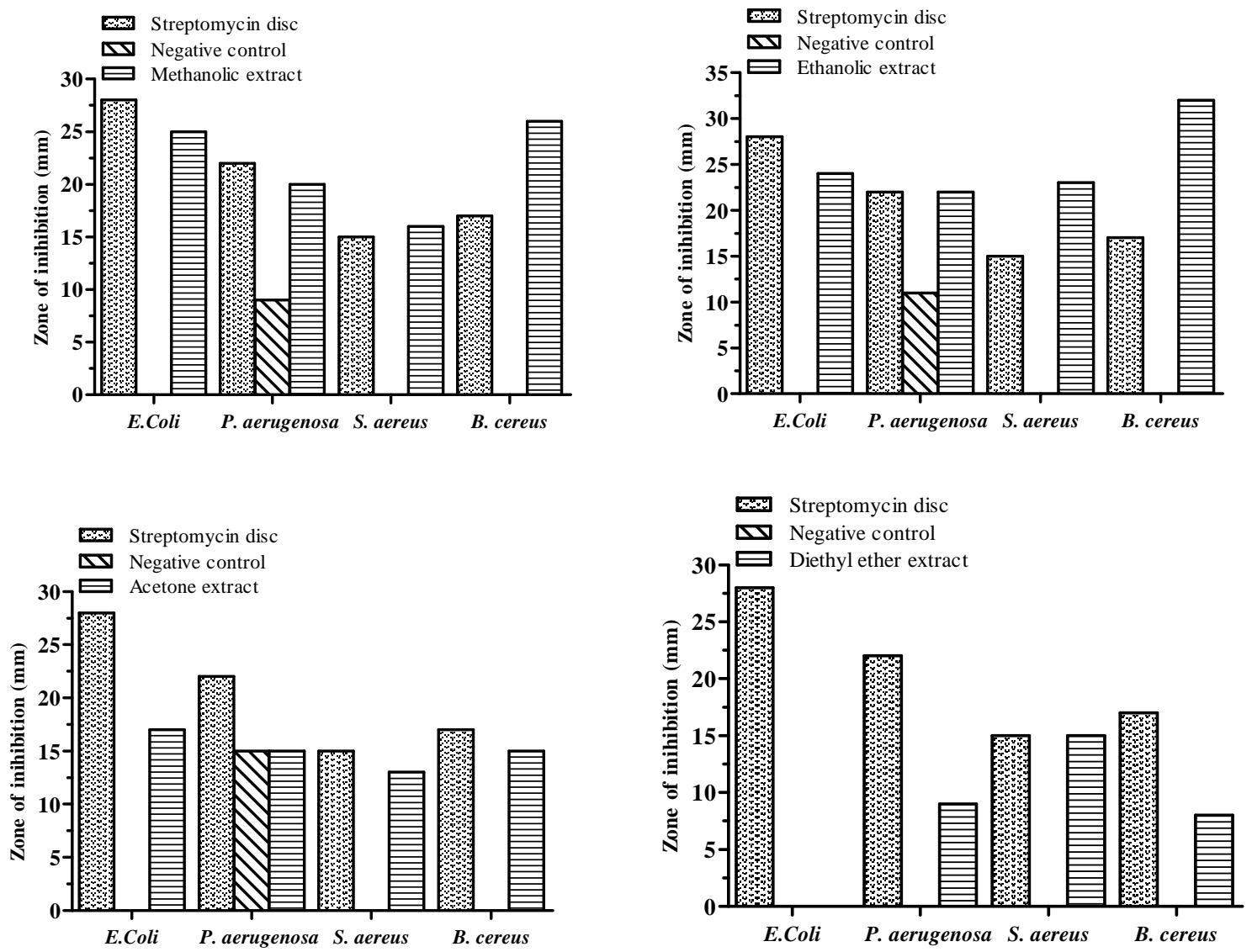

Figure 6

The plates showed antimicrobial activity of Spirogyra condensata against four pathogenic bacteria in four different solvents

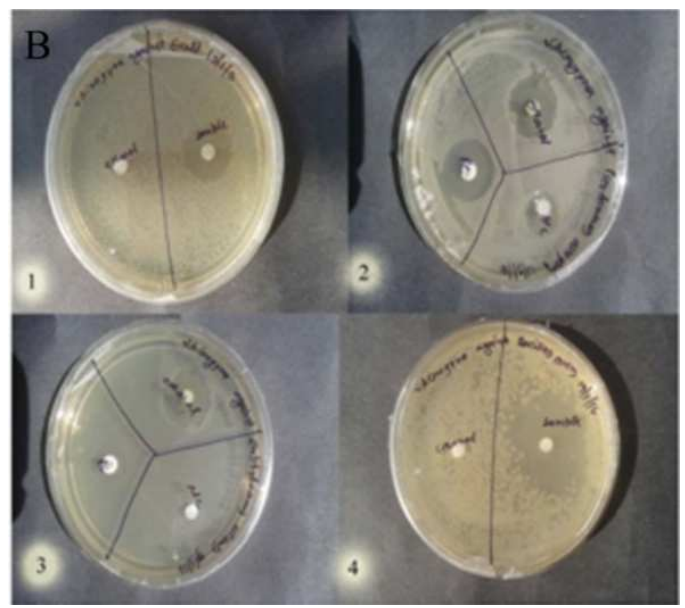

4. Spirogyra Condensata Shows the Maximum Antibacterial Activity in Methanolic Extract against $B$. cereus

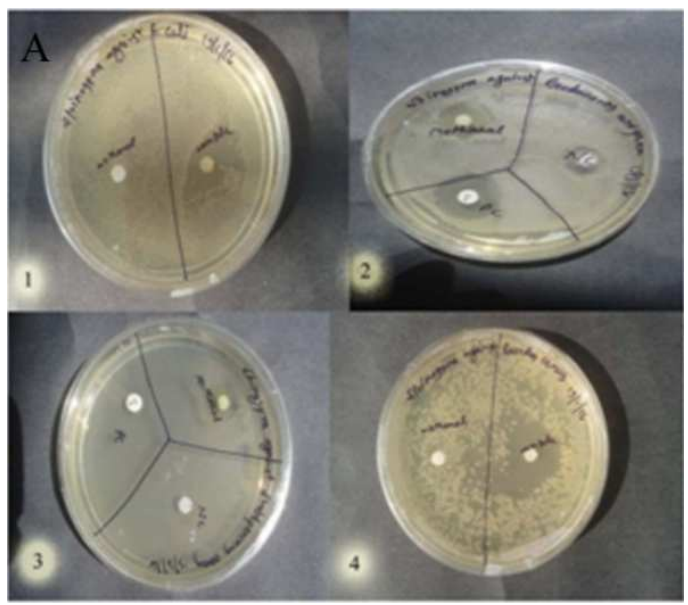

4. Spirogyra Condensata Shows the Maximum Antibacterial Activity in Ethanolic Extract against $B$. cereus 


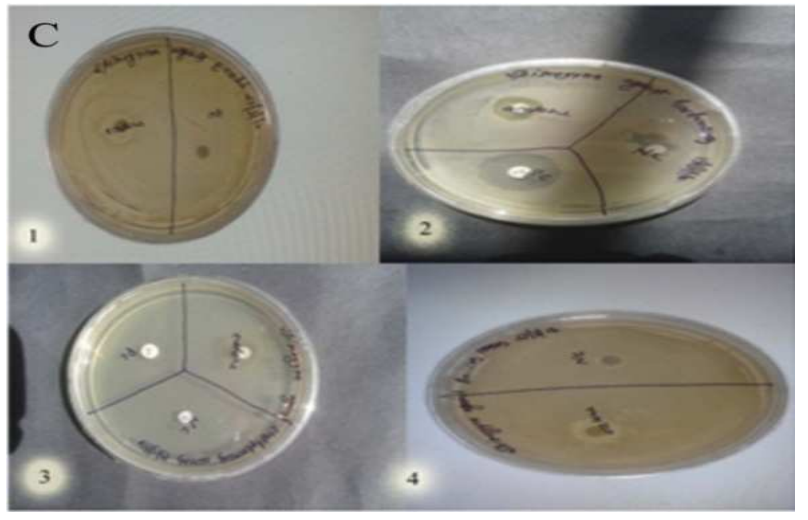

1. Spirogyra Condensata Shows the Maximum Antibacterial Activity in Acetone Extract against $E$. coli

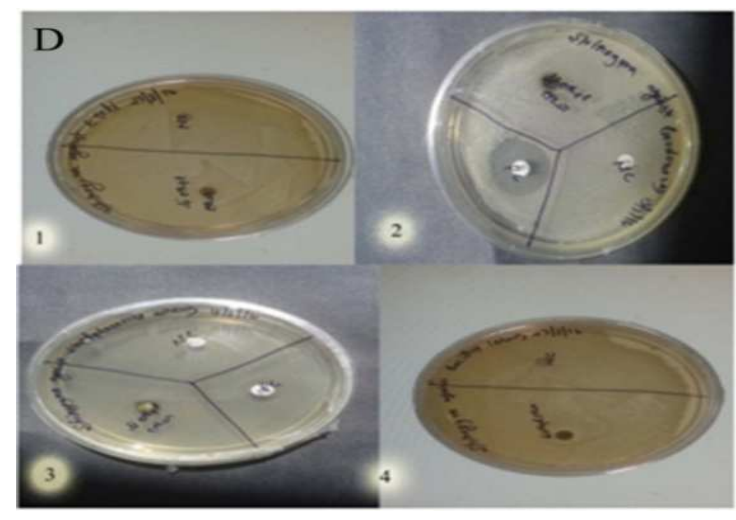

3. Spirogyra Condensata Shows the Maximum Antibacterial Activity in Diethyl Ether Extract against $S$. Aereus

Figure 7

A. Methanolic extract of Spirogyra shows antibacterial against four different bacteria (1) E. coli (2) P.aerugenosa (3) S.aereus (4) B. cereus

B. Ethanolic extract of Spirogyra shows antibacterial against four different bacteria (1) E. coli (2) P.aerugenosa (3) S. aereus (4) B.cereus

C. Acetone extract of Spirogyra shows antibacterial against four different bacteria (1) E. coli (2) P.aerugenosa (3) S.aereus (4) B. cereus

D. Diethyl ether extract of Spirogyra shows antibacterial against four different bacteria (1) E.coli (2) P. aerugenosa (3) S.aereus (4) B. cereus

\section{DISCUSSIONS}

Fresh water microalgae have become part of complementary medicine worldwide, because of their potential sources of bioactive molecules cause many health benefits in human being[25]. The present study results revealed that the ethanolic extract of Nannochloropsis oculata, Scenedesmus abundans and methanolic extract of Spirogyra condensata has shown maximum zone of inhibition against E. coli. This bacteria is gram negative, rod shaped caused many types of infection in human being like urinary tract infection, diarrhea, phylogenic infections and septicemia. The ethanolic extract of Nannochloropsis oculata, Scenedesmus abundans and methanolic extract of Spirogyra condensata has shown maximum zone of inhibition against $P$. aerugenosa. This bacterium is gram negative rod shaped, which caused many types of infection in human being like urinary tract infection, respiratory system infection, soft tissue infections, bone and joint infection. The ethanolic extract of Nannochloropsis oculata, Spirogyra condensata sp. and acetone extract of Scenedesmus abundans has shown maximum zone of inhibition against S. aureus. This bacteria is gram positive, rod shaped caused many types of infection in human being like sepsis in wounds and burns, septicemia, pharyngitis, sinusitis and tonsillitis. The ethanolic extract of Nannochloropsis oculata, Scenedesmus abundans and Spirogyra condensata sp. has shown maximum zone of inhibition against B. cereus. This bacterium is gram positive, rod shaped produce toxin, these toxins can cause two types of illness: one type characterized by diarrhea and the other, called emetic toxin, by nausea and vomiting[26]. In present study ethanolic crude extract of Nannochloropsis oculata was found more potent antibacterial activity against $B$. cereus as compared to antibiotic disc streptomycin. Acetone crude extract of Scenedesmus abundans 
was found more potent antibacterial activity against $S$. aureus as compared to antibiotic disc streptomycin. Beena et al. 2011 reported, The crude pigment extract of Scenedesmus abundans was found to have inhibitory activity against the food borne pathogen S. aureus[24] ethanolic crude extract of Spirogyra condensata was found more potent antibacterial activity against B. cereus, as compared to antibiotic disc streptomycin. It concludes that B. cereus and S. aureus, Gram - positive bacteria were more inhibited than Gram - negative bacteria E.coli and P. aeruginosa. Issa (1999) reported the antimicrobial activity of $\mathrm{O}$. angutissima and Calothrix parietal, against bacteria and fungi. He concluded that $B$. cereus and $S$. aureus, Gram- positive species were more inhibited than gram- negative species E. coli and P. aeruginosa by the antibiotic applied[23]. Ethanolic crude extract of Nannochloropsis oculata and Spirogyra condensata were found more potent antibacterial activity against B.cereus, P. aerugenosa, S.aereus and E.coli as compared to antibiotic disc streptomycin. Acetone crude extract of Scenedesmus abundans was more potent antibacterial activity against S.aereus as compared to antibiotic disc streptomycin. The result also proved that ethanol was the best solvent for the extracting the antibacterial and antifungal agents from Oscillatoria latevirens, while acetone was the best organic solvents for extracting antibacterial and antifungal agents from Phormidium corium and Lyngbya martensiana[22].

The present study indicates that the antibacterial property of Nannochloropsis oculata, Scenedesmus abundans and Spirogyra condensata against the selected strains of human pathogenic bacteria varies depending upon the four different solvent medium used for extraction. Further phytochemical studies are needed to elucidate the component responsible for antibacterial activity of these extracts against bacteria.

\section{Conflicts of Interest}

We declare that we have no conflict of interest.

\section{ACKNOWLEDGMENTS}

Authors are also thankful to the Director, National Botanical Research Institute, Lucknow for constant encouragement and necessary laboratory facilities.

\section{REFERENCES}

1. O. Pulz and W. Gross. "Valuable products from biotechnology of microalgae", Appl. Microbiol. Biotechnol 2004; 65, 635648.

2. Ely R. T. Supriya and C. G. NaaiK. Antimicrobial activity of marine organisms collected of the coast of South East India. J. Exp. Bio. Ecol 2004; 309:121-127.

3. Febles C.I., A. Arias and M.C. Gill-Rodriguez. Invitro study of antimicrobial activity in algae ( chlorophyta, Phaeophyta and Rhodophyta) collected from coast of Tenerife (in Spanish) Anuaria del Estudios Canarios 1995; 34:181-192.

4. Tuney, I., B.Cadirci, D, Unal and A. Sukatar. Antimicrobial activities of the extracts of marine algae from the coast of Urla ( izmir, Turkey) 2006; Turk. J.Biol., 30:171-175.

5. Noaman, N.H., A.F. Khaleafa and S.H. Zwky. Factors affecting antimicrobial activity of Synechococcus leopoliensis. Microbiol. Res 2004; 156: 359-402.

6. Overington JP, Al-Lazikani B, Hopkins AL. How many drug targets are there? Nat Rev Drug Discov 2006; 5: 993-996.

7. Pratt, R., Deniels, T.C., Eiler, J.J., Gunnison, J. B., Kumler, W. D., Oneto, J. F. et al. Chlorellin, an antibacterial substance from chlorella. Science 1944; 99 (2574): 351-352. 
8. Taskin E, Ozturk M, Taskin E, Kurt O. Antibacterial activities of some marine algae from the Aegean Sea (Turkey). Afr J Biotechnol 2007; 6: 2746-2751.

9. Rao M, malhotra S, Fatima T, Rattan A. Antimycobacterial activity from cyanobacterial extracts and phytochemical screening of methanol extract of Hapalosiphon. Pharm boil 2007; 45:88-93.

10. Falkowski, PG and Raven, J.A. Aquatic photosynthesis malden, MA: Blackwell Science 1997.

11. Lin J, Opoku AR, Keller MG, Hutchings AD, Terblanhe SE, Jager AK, et al. Preliminiary screening of some traditional Zulu Medicinal plants for anti- inflammatory and anti-microbial activities. J Ethnopharmacol 1998; 68: 267-274.

12. NARMS-National Resistance Monitoring System, 2002. Enteric Bacteria. CDC, USA.

13. NCCLS. Performance standards antimicrobial disc susceptibility tests. $5^{\text {th }}$ ed. PA: Villanova 1993; p. M2-A5.

14. Valgas, C,, de Souza, S. M., Smania Jr., A. Screening methods to determine antibacterial activity of natural products. Braz.J. Microbiol 2007; 38, 396-380.

15. Suseela, M. R., Antimicrobial activities of microalgae and cyanobacteria. Antimicrobial resistance: A Cause for Global Concern Narosa Pablishing House Pvt. Ltd 2014.

16. Srivastava N, Suseela MR \& Toppo K. Fresh water cyanobacteria of Sai River near Lucknow, Uttar Pradesh. Tropical Plant Research 2014; 1(2): 11-16].

17. Philipose, M.T. Chlorococcales, monograph on algae. Indian Council of Agricultural Research, New Delhi 1967; pp.365.

18. Prescott GW. Algae of the Western Great Lakes area. Cranbrook Institute of Science, Bloomfield Hills, Michigan, USA 1951; pp. 1-944.

19. Kannan RRR, Armugum R, Anantharaman P. In vitro antioxidant activities of ethanol extract from Enhalus acoroides (L.F.) Royle. Asian Pac J Trop Med 2010; 3(11): 898-901.

20. Pratt, R, Daniel, T.C., Eier, J.B., Gunnison, J.B., Kumler, W.D., Oneto, J.F., Strait, L.A., Spoehr, H.A., Harden, G.J., Milner, H.W., Smith, H. \& Strain H.H. Chlorellin. An antibacterial substance from chlorella. Science 1944; 99: 351-352.

21. Vijayakumar Madhumathi, Pitchai Deepa, Savarimuthu Jayachandran, Chockaiya Manoharan and Subramaniyan Vijayakumar. Antimicrobial activity of cyanobacteria isolated from freshwater lake. International Journal of Microbiological Research 2011; 2(3): 213-216.

22. Issa AA. Antibiotic production by Cyanobacteria Oscillatoria angustissima and Calothrix parietina. Environ. Toxicol. Pharmacol 1999; 8: 33-37.

23. Beena, B.N, R Krishnika, A. “Antibacterial activity of freshwater microalgae (Scenedesmus sp.) against three bacterial strains". Journal of Bioscience Resources, 2(4), 160-165.

24. Bhagavathy S, Sumathi P, Jancy Sherene Bell I. green algae Chlorococcum humicola-a new source of bioactive compounds with antimicrobial activity. Asian Pacific Journal of Tropical Biomedicine 2011; S1-S7.

25. Justella Wilfred prakash, Johnson Marimuthu@ Antonisamy, Solomon Jeeva. Antimicrobial activity of certain fresh water microalgae from Thamirabarani River, Tamil Nadu, South India. Asian Pacific Journal of Tropical Biomedicine 2011; S170S173.

26. Beena B. Nair and A. Krishnika. Antibacterial activity of freshwater Microalgae (Scenedesmus sp.) against three bacterial strains. Journal of Biosciences Research 2011; 2(4):160-165. 